\title{
Sex-related differences in hemato-biochemical indices of adult Vanaraja chickens during summer and winter seasons
}

Kuldeep Kumar Panigrahy ${ }^{1}$, Kumaresh Behera², Lal Mohan Mohapatra², Aditya Prasad Acharya ${ }^{3}$, Kamdev Sethy ${ }^{4}$, Sasmita Panda² and Shailesh Kumar Gupta ${ }^{1}$

1. Division of Livestock Production and Management, ICAR - National Dairy Research Institute (NDRI), Karnal - 132001 , Haryana, India; 2. Department of Livestock Production and Management, College of Veterinary Sciences and Animal Husbandry, Bhubaneswar - 751 003, Odisha, India; 3. Department of Veterinary Pathology, College of Veterinary Sciences and Animal Husbandry, Bhubaneswar - 751 003, Odisha, India; 4. Department of Animal Nutrition, College of Veterinary Sciences and Animal Husbandry, Bhubaneswar - 751 003, Odisha, India.

Corresponding author: Kuldeep Kumar Panigrahy, e-mail: kul.pani42@gmail.com,

KB: kumaresh.behera@gmail.com, LMM: Immohapatra@gmail.com, APA: dradityaaditya@gmail.com, KS: babuivri@gmail.com, SP: smileysas555@gmail.com, SKG: sgshailesh786@gmail.com

Received: 23-10-2016, Accepted: 13-01-2017, Published online: 13-02-2017

doi: 10.14202/vetworld.2017.176-180 How to cite this article: Panigrahy KK, Behera K, Mohapatra LM, Acharya AP, Sethy K, Panda S, Gupta SK (2017) Sex-related differences in hemato-biochemical indices of adult Vanaraja chickens during summer and winter seasons, Veterinary World, 10(2): 176-180.

\begin{abstract}
Aim: The objective of this study was to evaluate the changes in hemato-biochemical indices in male and female Vanaraja chickens under tropical environment during summer and winter season.

Materials and Methods: A total of 120 day-old sexed Vanaraja chicks were selected as experimental chickens and distributed equally in two groups having 60 female and 60 male chickens in each group, respectively. The experiment was continued for 8 weeks (56 days) and both male and female chickens were slaughtered by cervical dislocation method. All parameters were estimated at the end of the experiment in both seasons.

Results: Male had higher blood glucose, $\mathrm{Ca}$ and $\mathrm{P}$ level. Blood glucose level significantly $(\mathrm{p}<0.05)$ reduced in summer. Female had higher total protein, albumin, globulin, and albumin/globulin ratio. Alanine aminotransferase and aspartate aminotransferase enzyme concentration were significantly $(\mathrm{p}<0.05)$ higher in summer. Total erythrocyte count, total leukocyte count, hemoglobin $(\mathrm{Hb}), \mathrm{Hb} / \mathrm{lymphocyte}$ ratio, and packed cell volume were significantly $(\mathrm{p}<0.05)$ higher in males. Mean corpuscular volume and mean corpuscular $\mathrm{Hb}$ were significantly $(\mathrm{p}<0.05)$ higher in females.

Conclusion: Sex of chickens had a significant $(p<0.05)$ effect on different parameters whereas season had nonsignificant $(\mathrm{p}>0.05)$ effect in most of the observed parameters. Hence, Vanaraja chickens are adaptable to local tropical climate and can be reared efficiently as backyard poultry.
\end{abstract}

Keywords: indices, season, tropical climate, Vanaraja chicken, welfare.

\section{Introduction}

Vanaraja is a multi colored synthetic backyard chicken developed by Project Directorate of Poultry Research, Hyderabad. Backyard poultry sector has major contribution toward strengthening of rural economy in India. Hence, it is necessary to study adaptability of these chickens by measuring the changes in different key indicators. Among all indices, hemato-biochemical parameters are promising indicators of physiological status and environment effect [1]. Hence, these indices are important for diagnosis and treatment of diseases and for measuring the environmental stress in chickens. The effect of season and sex on hemato-biochemical parameters were reported by many previous researchers $[2,3]$. Due to increased environmental temperature and

Copyright: Panigrahy, et al. Open Access. This article is distributed under the terms of the Creative Commons Attribution 4.0 International License (http://creativecommons.org/licenses/ by/4.0/), which permits unrestricted use, distribution, and reproduction in any medium, provided you give appropriate credit to the original author(s) and the source, provide a link to the Creative Commons license, and indicate if changes were made. The Creative Commons Public Domain Dedication waiver (http:// creativecommons.org/publicdomain/zero/1.0/) applies to the data made available in this article, unless otherwise stated. humidity, there was marked reduction in performance of Vanarajachickens [4]. However, in some experiments, it was found that Vanaraja chickens are highly adapted to the local environment with intensive housing system [5]. In tropical climate indigenous chickens expressed low-stress condition than that of commercial strain [6].

Total protein, albumin and globulindecreases due to high environmental temperature. In Cobb broilers, total protein and albumin concentration decreases when ambient temperature increases above $30^{\circ} \mathrm{C}$. Decreased plasma glucose concentration from 206 to $192 \mathrm{mg} / \mathrm{dl}$ was observed in broiler due to heat stress. Serum enzyme level is good indicator of physiological status of chickens. Different biochemical parameters - such as total protein, albumin, globulin, aspartate aminotransferase (AST), alanine aminotransferase (ALT), Ca and P - are also affected by sex of the chickens [2]. Higher level of total plasma protein was observed in females in comparison to males. Increased level of ALT and AST was observed in broiler chicken above $32^{\circ} \mathrm{C}$ temperature for 5 weeks of exposure. Significantly higher level of $\mathrm{Ca}$ and $\mathrm{P}$ was observed in female chicken [7]. Heat 
stress had significant effect on $\mathrm{Ca}$ and $\mathrm{P}$ level in chickens. Contrary to this, no significant effect ofheatwas observed in Ca level [8]. A significant effect of season was observed in Leghorn chickens and hemoglobin $(\mathrm{Hb})$, packed cell volume (PCV), andtotal erythrocyte count (TEC) values changes during the heat stress in summer [9]. Sex-dependent variability was observed in blood hematological parameters such as PCV, TEC, total erythrocyte count (TLC), and different leukocytes cell counts in Indigenous chicken [2]. Contrary to this in local Saudi chicken, these parameters were found higher in male compared to female [10]. Most of the hematological parameters were higher in males than females [11]. Higher level of TEC, PCV, and $\mathrm{Hb}$ concentration was observed in males due to effect of androgen. Nonsignificant effect of age on mean corpuscular volume (MCV), mean corpuscular $\mathrm{Hb}$ $(\mathrm{MCH}), \mathrm{MCH}$ concentration (MCHC), and differential leukocyte count was observed in local Saudi chicken [10]. Changes in MCHC and MCV between male and female were observed previously [11]. Changes in season also effect MCH and MCHC level were reported in previous experiments [8].

Findings on hemato-biochemical parameters by different Indian scientists [7,12] related to sex and season were available. There is little information about effect of season and sex on hemato-biochemical parameters of Vanaraja chickens. Hence, this experiment was conducted to investigate the effect of sex and season on hemato-biochemical parameters in Vanaraja chickens which will be helpful in evaluating the physiological and health status of the Vanaraja chickens.

\section{Materials and Methods}

\section{Ethical approval}

The research work was conducted in the Instructional Livestock Farm Complex, College of Veterinary Science and Animal Husbandry, Orissa University of Agriculture and Technology, Bhubaneswar, Odisha. The prior ethical approval from the Institutional Animal Ethics Committee, OUAT, College of Veterinary Science and Animal Husbandry, Bhubaneswar, Odisha-751003, was obtained for the use of animal in this study.

\section{Experimental design}

A total of 120 Vanaraja chicks ( 60 male +60 female) were used for the experiment in each season. In each season, male and female chickens were divided into separate groups. The feeding and management of both groups were similar according to standard norms. Deep litter rearing arrangements were prepared 2 days before arrival of chicks. The deep litter house was divided into two compartments using wire netting. All chickens were marked using wing bands on $1^{\text {st }}$ day. Vaccination of chickens was done regularly according to standard guidelines. All chickens were fed as per BIS standard. The composition of dietis presented in Table-1.

The duration of experiments was for 8 weeks during winter $\left(1^{\text {st }}\right.$ December to $30^{\text {th }}$ January) and
Table-1: Ingredients (\%) of broiler starter and finisher diets.

\begin{tabular}{lccc}
\hline $\begin{array}{l}\text { Components } \\
\text { (\% DM basis) }\end{array}$ & Pre-starter & Starter & Finisher \\
\hline Dry matter & $88.82^{\mathrm{a}}$ & $89.16^{\mathrm{a}}$ & $89.32^{\mathrm{a}}$ \\
Crude protein & $22.92^{\mathrm{a}}$ & $21.88^{\mathrm{b}}$ & $19.65^{\mathrm{c}}$ \\
Metabolizable energy* & $2970^{\mathrm{a}}$ & $3092^{\mathrm{b}}$ & $3166^{\mathrm{c}}$ \\
(kcal/kg) & & & \\
Ether extract & $3.09^{\mathrm{a}}$ & $3.56^{\mathrm{a}}$ & $4.11^{\mathrm{b}}$ \\
Crude fiber & $5.16^{\mathrm{a}}$ & $4.82^{\mathrm{b}}$ & $5.29^{\mathrm{a}}$ \\
Nitrogen free extract & $64.91^{\mathrm{a}}$ & $65.23^{\mathrm{b}}$ & $66.32^{\mathrm{c}}$ \\
Acid insoluble ash & $2.56^{\mathrm{a}}$ & $2.52^{\mathrm{a}}$ & $2.49^{\mathrm{a}}$ \\
Calcium & $0.96^{\mathrm{a}}$ & $0.95^{\mathrm{a}}$ & $0.99^{\mathrm{b}}$ \\
Phosphorous & $0.72^{\mathrm{a}}$ & $0.71^{\mathrm{a}}$ & $0.69^{\mathrm{a}}$ \\
\hline Values bearing dfferent & & &
\end{tabular}

Values bearing different superscripts within a row differed significantly $(p<0.05)$

summer ( $1^{\text {st }}$ April to $30^{\text {th }}$ May).The experimental chickens were randomly divided into two groups,

1. Treatment- 1: Male Vanaraja - 60 chickens

2. Treatment- 2: Female Vanaraja - 60 chickens.

Collection of blood sample and separation of serum

For hematological study, blood samples were collected aseptically at the end of theexperiment in summer and winter season of 30 selected chickens inethylenediaminetetraacetic acid containing vial. Blood samples were also collected for separation of serum and stored at $-20^{\circ} \mathrm{C}$ for further use. These serum samples were used for biochemical studies. $\mathrm{Hb}$ was estimated using Sahli'shemoglobinometer; TEC using Neubauer chamber; other erythrocytes indices such as $\mathrm{MCV}, \mathrm{MCH}$, and $\mathrm{MCHC}$ were estimatedusing the standard formulae.The ALT and AST estimations were done after $24 \mathrm{~h}$ of collection. The serum biochemical parameters were estimated using kits AutoSpan Liquid Gold Diagnostic, India.

\section{Statistical analysis}

The different hemato-biochemical parameters in male and female chickens were statistically analyzed using Statistical Package for Social Science version 17.0. Descriptive statistics in theform of mean \pm standard error was used to measure all the parameters. Significance level was fixed at $5 \%$ level and $\mathrm{p}<0.05$ were considered as significant.

\section{Results and Discussion}

\section{Effect of sex and season on blood biochemical parameters}

The biochemical parameters of male and female Vanaraja chickens during summer and winter are presented in Table-2. Male had significantly $(p<0.05)$ higher blood glucose levelin both seasons than females. Contrary to this finding previous studies showed nonsignificant differences in glucose concentration between male and female $[2,8,10]$. This finding was opposite to finding in Aseel female chickens [7] where a higher level of glucose found in female chicken. Blood glucose level may increase with increase in temperature upto $305.95 \pm 3.23 \mathrm{mg} / \mathrm{dl}$ at $40-45^{\circ} \mathrm{C}$ in broiler chicken. In our study during summer 
Table-2: Blood biochemical parameters of male and female Vanaraja chickens during summer and winter.

\begin{tabular}{|c|c|c|c|c|}
\hline \multirow[t]{2}{*}{ Parameters } & \multicolumn{2}{|c|}{ Winter season } & \multicolumn{2}{|c|}{ Summer season } \\
\hline & Male & Female & Male & Female \\
\hline Glucose (mg/dl) & $210.36 \pm 8.35^{\mathrm{aA}}$ & $179.89 \pm 5.67^{\text {bв }}$ & $186.34 \pm 7.39^{\mathrm{cc}}$ & $156.67 \pm 4.89 \mathrm{dD}$ \\
\hline Total protein (g/dl) & $3.34 \pm 0.21^{\mathrm{aA}}$ & $4.02 \pm 0.26^{\mathrm{bB}}$ & $3.36 \pm 0.11^{\mathrm{aA}}$ & $3.99 \pm 0.15^{\mathrm{bB}}$ \\
\hline Albumin (g/dl) & $1.98 \pm 0.03^{\mathrm{aA}}$ & $2.57 \pm 0.06^{\mathrm{bB}}$ & $1.95 \pm 0.05^{\mathrm{aA}}$ & $2.50 \pm 0.07^{\mathrm{bB}}$ \\
\hline Globulin (g/dl) & $1.36 \pm 0.026^{\mathrm{aA}}$ & $1.45 \pm 0.05^{\mathrm{bB}}$ & $1.39 \pm 0.11^{\mathrm{aA}}$ & $1.49 \pm 0.03^{\mathrm{bB}}$ \\
\hline $\mathrm{A} / \mathrm{G}$ ratio & $1.45 \pm 0.06^{\mathrm{aA}}$ & $1.77 \pm 0.03^{\mathrm{bB}}$ & $1.40 \pm 0.08^{\mathrm{aA}}$ & $1.67 \pm 0.04^{\mathrm{bB}}$ \\
\hline Cholesterol (mg/dl) & $182.35 \pm 0.30^{\mathrm{aA}}$ & $181.21 \pm 0.32^{\mathrm{aA}}$ & $186.11 \pm 0.24^{\mathrm{aA}}$ & $184.19 \pm 0.26^{\mathrm{aA}}$ \\
\hline $\operatorname{ALT}(\mathrm{IU} / \mathrm{L})$ & $27.29 \pm 1.29^{\mathrm{aA}}$ & $26.86 \pm 1.12^{\mathrm{aA}}$ & $46.38 \pm 1.36^{\mathrm{bB}}$ & $43.55 \pm 1.98^{\mathrm{bB}}$ \\
\hline AST (IU/L) & $383.82 \pm 8.28^{\mathrm{aA}}$ & $379.27 \pm 14.78^{\mathrm{aA}}$ & $412.65 \pm 9.36^{\mathrm{bB}}$ & $399.35 \pm 7.67^{\mathrm{bB}}$ \\
\hline Calcium (mg/dl) & $9.89 \pm 0.29^{\mathrm{aA}}$ & $7.33 \pm 0.17^{\mathrm{bB}}$ & $9.71 \pm 0.39^{\mathrm{aA}}$ & $7.21 \pm 0.23^{\mathrm{bB}}$ \\
\hline Phosphorus (mg/dl) & $5.89 \pm 0.31^{\mathrm{aA}}$ & $4.08 \pm 0.19^{\mathrm{aA}}$ & $5.23 \pm 0.28^{\mathrm{aA}}$ & $4.81 \pm 0.11^{\mathrm{bB}}$ \\
\hline
\end{tabular}

Values bearing different superscripts within a row in a single season differed significantly $(p<0.05)$.

$\mathrm{A} / \mathrm{G}=$ Albumin/globulin, AST=Aspartate aminotransferase, ALT=Alanine aminotransferase

season, the level of glucose was significantly $(\mathrm{p}<0.05)$ lower both in male and female than winter season. Previously increased blood glucose level was observed in chickens due to heat stress in summer [13]. This may be due to low feed intake during summer. No significant effectson blood glucose level observed in summer which is opposite tothe findings in previous study [13]. It may be due to negligible impact of heat in Vanaraja chickens in this study. Total protein, albumin and globulin concentration were significantly $(p<0.05)$ higher in female in both season. The total protein level inthis study was similar to the finding of former study [13]. Similar to our result, increased total protein in female was observed in Aseel chickens [7], Nigerian local chicken [14], and Indigenous chickens [2]. This finding was contrary to the finding in Turkey under arid tropical environment [15]. Increased albumin concentration in females was similar to finding in Aseel chickens [7] and Nigerian local chicken [14]. This may be due to many physiological influences in female chickens. Significantly $(p<0.05)$ high globulin concentration in female during both season is similar to finding in Turkey [15]. Nonsignificant $(p>0.05)$ difference of total protein, albumin and globulin was observed in both season. Contrary to this, increased level of total protein was observed inthe previous experiment [13]. This may be due to increased heat stress on chickens during summer. No significant difference was observed in albumin concentration between winter and summer season. This finding was opposite to the observation in Ross strain broiler [8] and in Turkey under arid tropical environment [15]. Albumin/globulin (A/G) ratio was significantly higher in females in both seasons than males. There was nonsignificant $(p>0.05)$ effect of season on $\mathrm{A} / \mathrm{G}$ ratio but it slightly reduced in males. Nonsignificant $(p>0.05)$ difference was observed in total cholesterol concentration between male and female in both seasons. This observation is similar to finding of Abdi-Hachesoo et al. [2].Contrary to this, increased level of cholesterol was observed in female Assel chickens [7]. During summer, the cholesterol level was nonsignificantly higher in both male and females than winter. Increased level of cholesterol in summer was observed previously in many experiments. This finding supported a view of minor effect of summer stress in chickens. Nonsignificant $(p>0.05)$ differences were observed in ALT and AST enzyme concentration between male and female in both seasons which is similar to finding of Abdi-Hachesoo et al. [2]. The ALT and AST enzyme concentration were significantly $(p<0.05)$ higher in summer than winter.The serum concentration of $\mathrm{Ca}$ and $\mathrm{P}$ was significantly $(p<0.05)$ higher in males in both seasons. Increased serum $\mathrm{Ca}$ and $\mathrm{P}$ in males in both seasons were similar to the finding of Abdi-Hachesoo et al. [2], Isidahomen et al. [14]. Contrary to this, higher level of $\mathrm{Ca}$ and $\mathrm{P}$ was observed in female Aseel chickens [7]. There was nonsignificant effect of season on $\mathrm{Ca}$ and $\mathrm{P}$ level. Contrary to this, increased $\mathrm{P}$ level was observed in Ross, Cobb and Hubbard broiler [8].

\section{Effect of sex and season on blood hematological parameters}

The hematological parameters of male and female during summer and winter of Vanaraja chickens are presented in Table-3. Total TEC and Hb count were significantly $(p<0.05)$ higher in males than females in both seasons. TEC and $\mathrm{Hb}$ concentration are lower than the finding in the previous study [12]. Higher level of TEC count in males is similar to the finding in Vanaraja chickens [12], colored broiler chickens [16], and Nigerian local chicken [14]. Higher level of $\mathrm{Hb}$ concentration in male Vanaraja chickens was also observed in the previous study [14]. Nonsignificant $(p>0.05)$ differences were observed in TEC and $\mathrm{Hb}$ between summer and winter in both sexes. This finding is similar to the findings in Ross, Cobb, and Hubbard strain [8]. Contrary to this, higher level of TEC was observed during winter than summer season in Leghorn chickens at 40 weeks [9]. Decreased level of TEC was found due to high environment temperature stress. Significant effect of season on $\mathrm{Hb}$ concentration was observed in Ross and Cobb broiler [8] and Leghorn chickens at 40 weeks [9]. In both cases, $\mathrm{Hb}$ concentration increased due to heat stress for adaptation of chickens in changed environment. The total 
Table-3: Blood hematological parameters of male and female Vanaraja chickens during summer and winter season.

\begin{tabular}{|c|c|c|c|c|}
\hline \multirow[t]{2}{*}{ Parameters } & \multicolumn{2}{|c|}{ Winter } & \multicolumn{2}{|c|}{ Summer } \\
\hline & Male & Female & Male & Female \\
\hline TEC (millions $/ \mathrm{mm}^{3}$ ) & $2.96 \pm 0.13^{\mathrm{aA}}$ & $1.62 \pm 0.12^{\mathrm{bB}}$ & $2.59 \pm 0.09^{\mathrm{aA}}$ & $1.29 \pm 0.06^{\mathrm{bB}}$ \\
\hline $\mathrm{Hb}(\mathrm{g} / \mathrm{dl})$ & $14.31 \pm 0.21^{\mathrm{aA}}$ & $11.11 \pm 0.32^{\mathrm{bB}}$ & $13.92 \pm 0.20^{\mathrm{aA}}$ & $10.54 \pm 0.19^{\mathrm{bB}}$ \\
\hline $\operatorname{TLC}\left(10^{3} / \mu \mathrm{l}\right)$ & $63.59 \pm 0.65^{\mathrm{aA}}$ & $49.81 \pm 0.98^{\mathrm{bB}}$ & $62.38 \pm 0.51^{\mathrm{aA}}$ & $48.98 \pm 0.73^{\mathrm{bB}}$ \\
\hline Lymphocyte (\%) & $66.54 \pm 0.33^{\mathrm{aA}}$ & $64.33 \pm 0.26^{\mathrm{aA}}$ & $67.31 \pm 0.28^{\mathrm{aA}}$ & $67.07 \pm 0.31^{\mathrm{aA}}$ \\
\hline Heterophil (\%) & $26.72 \pm 0.16^{\mathrm{aA}}$ & $27.88 \pm 0.26^{\mathrm{aA}}$ & $26.67 \pm 0.22^{\mathrm{aA}}$ & $25.87 \pm 0.21^{\mathrm{aA}}$ \\
\hline Monocyte (\%) & $4.43 \pm 0.2^{\mathrm{aA}}$ & $4.39 \pm 0.39^{\mathrm{aA}}$ & $3.81 \pm 0.21^{\mathrm{aA}}$ & $4.68 \pm 0.33^{\mathrm{aA}}$ \\
\hline Eosinophil (\%) & $2.31 \pm 0.31^{\mathrm{aA}}$ & $2.30 \pm 0.11^{\mathrm{aA}}$ & $2.21 \pm 0.29^{\mathrm{aA}}$ & $2.38 \pm 0.13^{\mathrm{aA}}$ \\
\hline Basophil (\%) & 0 & 0 & 0 & 0 \\
\hline $\mathrm{H} / \mathrm{L}$ ratio & $0.40^{\mathrm{aA}}$ & $0.43^{\mathrm{aA}}$ & $0.39^{\mathrm{aA}}$ & $0.38^{\mathrm{aA}}$ \\
\hline PCV (\%) & $52.61 \pm 0.68^{\mathrm{aA}}$ & $46.31 \pm 0.5^{\mathrm{bB}}$ & $49.28 \pm 0.41^{\mathrm{aA}}$ & $42.39 \pm 0.62^{\mathrm{bB}}$ \\
\hline MCV (fl/cell) & $138.54 \pm 4.89^{\mathrm{aA}}$ & $142.54 \pm 5.41^{\mathrm{bB}}$ & $114.31 \pm 6.48^{a c}$ & $118.54 \pm 6.31^{\mathrm{bD}}$ \\
\hline $\mathrm{MCH}$ (pg/cell) & $46.17 \pm 1.36^{\mathrm{aA}}$ & $53.32 \pm 1.19^{\text {вв }}$ & $39.87 \pm 0.98^{\mathrm{ac}}$ & $45.89 \pm 0.65^{\mathrm{bD}}$ \\
\hline $\mathrm{MCHC}(\mathrm{g} \%)$ & $35.61 \pm 0.65^{\mathrm{aA}}$ & $36.03 \pm 0.98^{\mathrm{aA}}$ & $36.53 \pm 0.51^{\mathrm{aA}}$ & $36.98 \pm 0.73^{\mathrm{aA}}$ \\
\hline
\end{tabular}

Values bearing different superscripts within a row in a single season differed significantly $(p<0.05)$. Hb=Hemoglobin, $\mathrm{TEC}=$ Total erythrocyte count, $\mathrm{TLC}=$ Total erythrocyte count, $\mathrm{H} / \mathrm{L}=$ Hemoglobin/lymphocyte ratio, $\mathrm{PCV}=$ Packed cell volume, $\mathrm{MCV}=$ Mean corpuscular volume, $\mathrm{MCH}=$ Mean corpuscular hemoglobin, $\mathrm{MCHC}=$ Mean corpuscular hemoglobin concentration

TLC count was significantly $(\mathrm{p}<0.05)$ higher in males than females in both seasons. In study of differential leukocyte counts (DLCs) (lymphocyte, heterophiles, monocytes, eosinophiles, and basophiles), no significant $(\mathrm{p}>0.05)$ difference was observed between male and female.TLC was lower than the finding in the previous study in Nicobari fowls [12]. Higher level of TLC count in males than females is similar to the report of Abdi-Hachesoo et al. [2], Albokhadaim et al. [10], and Isidahomen et al. [14]. The higher level of TLC in males may be due to the sexual hormone effect [2] or inherent sex difference. Earlier, no difference between different white blood cells between male and female with low value of TLC in females was observed in Sudanese indigenous chicken [17]. The percentage of sex-independent different leukocytes was also similar to the finding of Albokhadaim et al. [10]. Lymphocyte was a predominant TLC in both sexes. This is similar to the previous findings [2]. Nosignificant $(p>0.05)$ effect of season was found in TLC and DLC. TLC was lower than the finding in the previous study in Nicobari fowls [12]. Higher level of TLC count in males than females is similar to earlier reports $[2,10,14]$. The higher level of TLC in males may be due to sex hormone effect [2] or inherent sex difference. Earlier, no difference between different white blood cells between male and female with low value of TLC in females was observed in Sudanese indigenous chicken [17]. The percentage of sex-independent different leukocytes was also similar to the previous findings [10]. Nonsignificant $(\mathrm{p}>0.05)$ differences were observed in Hb/lymphocyte ratio $(\mathrm{H} / \mathrm{L})$ ratio between male and female in both seasons. Contrary to our finding increased $\mathrm{H} / \mathrm{L}$ ratio was observed in many experiments. $\mathrm{H} / \mathrm{L}$ ratio may be increased from 0.39 to 0.56 in summer in broiler due to stress. Change in $\mathrm{H} / \mathrm{L}$ ratio is a good indicator of stressful condition. PCV (\%) was significantly $(p<0.05)$ higher in males than females in both seasons. Higher values of PCV (\%) in males were reported in many experiments $[11,14]$. The higher level of PCV reportedin males due to effect of androgens [2]. There was no significant $(\mathrm{p}>0.05)$ effect of season on PCV $(\%)$. Contrary to our finding, a decreased PCV (\%) was observed in Cobb and Hubbard strains and in leghorn chickens [8]. MCV and $\mathrm{MCH}$ was significantly $(p<0.05)$ higher in females in both season. Contrary to this finding higher value of $\mathrm{MCV}$ and $\mathrm{MCHC}$ was reported in male Nigerian local chicken [14]. No significant ( $p>0.05$ ) differences were observed in $\mathrm{MCHC}$ between male and female. MCV and $\mathrm{MCH}$ were significantly $(p<0.05)$ decreased in summer season in both sexes. Nonsignificant ( $p>0.05$ ) MCHC value was observed between winter and summer.Higher level of $\mathrm{MCHC}$ in females and MCV in males and no difference in $\mathrm{MCH}$ between male and female was reported [11]. Contrary to our decreased MCV level in summer, previously many authors reported an increased level of $\mathrm{MCV}$ during summer due to heat stress. Further, $\mathrm{MCH}$ was decreased significantly $(\mathrm{p}<0.05)$ in summer season in both sexes. Decreased MCH was also reported in Ross and Cobb strains [8]. This may be due to nonsignificant $(p>0.05)$ reduction in $\mathrm{Hb}$ concentration during summer. Nonsignificant $(\mathrm{p}>0.05)$ effect of season on $\mathrm{MCHC}$ were similar to the findings in Leghorn chickens [9] and Sudanese chicken ecotype [17]. Contrary to this report a low MCHC level was observed in Ross, Cobb and Hubbard strain [8].

\section{Conclusion}

Among biochemical parameters, higher blood glucose, $\mathrm{Ca}$ and $\mathrm{P}$ level was observed in males. Blood glucose level significantly $(p<0.05)$ reduced in summer. Female had higher total protein, albumin, globulin, and A/G ratio. ALT and AST enzyme concentration was significantly $(p<0.05)$ higher in summer. Among hematological parameters, TEC, TLC, Hb, $\mathrm{H} / \mathrm{L}$ ratio and $\mathrm{PCV}$ was significantly $(\mathrm{p}<0.05)$ higher in males. Lymphocyte was a predominant TLC in both sexes. MCV and MCH were significantly $(p<0.05)$ 
higher in females. Effect of season was observed in $\mathrm{MCV}$ and $\mathrm{MCH}$.

From this study, it is concluded that sex of chickens had a significant $(\mathrm{p}<0.05)$ effect on different parameters, whereas season had nonsignificant $(p>0.05)$ effect in most of the observed parameters. Hence, Vanaraja chickens are adaptable to local tropical climate and can be reared as backyard poultry.

\section{Authors' Contributions}

$\mathrm{KKP}, \mathrm{KB}$, and LM designed the plan of work. $\mathrm{APA}, \mathrm{KKP}$, and $\mathrm{KB}$ performed laboratory investigation. KS and SP helped in the laboratory investigations. KKP, KB, KS, SP, and SKG participated in draftand revision of the manuscript. All authors read and approved the final manuscript.

\section{Acknowledgments}

The authors acknowledge the fund and infrastructural facilities provided by Dean, College of Veterinary and Animal Sciences, Orissa University of Agriculture and Technology, Bhubaneswar under PG research program of first author. We are equally grateful to the technical staff of Department of Veterinary Pathology for their cooperation throughout the study.

\section{Competing Interests} interests.

The authors declare that they have no competing

\section{References}

1. Ajakaiye, J.J., Perez-Bellow, A. and Mollineda-Trujillo, A. (2010) Impact of vitamin C and E in dietary supplementation on leukocyte profile of layer hens exposed to high ambient temperature and humidity. Acta Vet. Brno, 79: $377-383$

2. Abdi-Hachesoo, B., Talebi, A., Asri-Rezaei, S. and Basaki, M. (2013) Sex related differences in biochemical and hematological parameters of adult indigenous chickens in Northwest of Iran. J. Anim. Sci. Adv.,3(10): 512-516.

3. Kececi, T. and Col, R. (2011) Haematological and biochemical values of the blood of pheasants (Phasianuscolchicus) of different ages. Turk. J. Vet. Anim. Sci., 35(3): 149-156.

4. Baba, I.A., Singh, Y. and Thirumurugan, P. (2014) Performance of Vanarajachickens under different climatic parameters. J. World's Poult. Res., 4(1): 1-4.

5. Sankhyan, V. and Thakur, Y.P. (2016) Comparative performance of Vanaraja and indigenous chicken under intensive system in subtemperate climatic condition of North Western Himalayan state of Himachal Pradesh. Int.J. Sci.Environ. Technol., 5(2): 449-453.

6. Tirawattanawanich, C., Chantakru, S., Nimitsantiwong, W. and Tongyai, S. (2011) The effects of tropical environmental conditions on the stress and immune responses of commercial broilers, Thai indigenous chickens, and crossbred chickens. J. Appl.Poult. Res., 20(4): 409-420.

7. Kumar, B. and Kumbhakar, N.B. (2015) Haematobiochemical profile of Aseel in Chhattisgarh region. Indian Vet. J., 92(1): 40-42.

8. Mohamed, E.A.A., Ali, O.H.A., Malik, E.E.H. and Yousif, I.A. (2012) Effect of season and dietary protein level on some haematological parameters and blood biochemical compositions of three broiler strains.Int. J. Poult. Sci., 11(12): 787-793.

9. Pandian, C., Pandiyan, M.T., Sundaresan, A. and Omprakash, A.V. (2012) Haematological profile and erythrocyte indices in different breeds of poultry. Int. J. Livest. Res., 2(3): 89-92.

10. Albokhadaim, I., Althnaian, T. and El-Bahr, S.M. (2012) Investigation of selected biochemical parameters of local chickens with different age and sex in Al-Ahsa, Saudi Arabia. Pak. J. Biol. Sci., 15(17): 827-832.

11. Addass, P.A., David, D.L., Edward, A., Zira, K.E. and Midau, A. (2012) Effect of age, sex and management system on some haematological parameters of intensively and semi-intensively kept chicken in Mubi, Adamawa state, Nigeria. Iran. J. Appl. Anim. Sci., 2(3): 277-282.

12. Kundu, A., De, A.K., Kundu, M.S., Sunder, J. and Jeyakumar, S. (2013) Comparative haematology of Vanaraja, Nicobari fowls and their various $F_{1}$ crosses under hot humid climate of Andaman and Nicobar Islands, India. Vet. World, 6(12): 1008-1011.

13. Aarif, O., Shergojry, S.A., Dar, S.A., Khan, N., Mir, N.A. and Sheikh, A.A. (2014) Impact of cold stress on blood biochemical and immune status in male and female Vanaraja chickens. Indian J. Anim. Res., 48(2): 139-142.

14. Isidahomen, E.C., Ozoje, M.O. and Njidda, A.A. (2011) Haematological and serum biochemical indices of local and exotic chickens in a subhumid tropical environment. Eur. $J$. Biol. Sci., 3(1): 16-21.

15. Gattani, A., Pathak, A., Kumar, A., Mishra, V. and Bhatia, J.S. (2016) Influence of season and sex on hematobiochemical traits in adult turkeys under arid tropical environment. Vet. World, 9(5): 530-534.

16. Prahsanth, B., Kumar, V.G., Narasimhamurthy, H.N. and Nandi, S. (2012) Blood haematological and biochemical parameters in domestic chicken (Gallus gallusdomesticus) with respect to strain, age and sex. Indian J. Poult. Sci., 47(3): 340-344.

17. Elagib, H.A.A. and Ahmed, A.D.A. (2011) Comprative study of hematological values of indigenous chicken in Sudan. Asian J. Poult. Sci., 5(1): 41-45. 